\title{
IMPLEMENTASI PERMAINAN DOMINO UNTUK MENINGKATKAN KEMAMPUAN KOGNITIF DAN MINAT BELAJAR SISWA KELAS V PADA PELAJARAN IPS DI SDN KEMUNING KECAMATAN SAMBIT KABUPATEN PONOROGO
}

\author{
Dian Nur Antika Eky Hastuti \\ nurantika27@ikippgrimadiun.ac.id \\ IKIP PGRI MADIUN
}

\begin{abstract}
In the learning at school teachers play an important role to create an environment learned that can stimulate students with a maximum development. This study use sthe design of Classroom Action Research is done in two cycles. Data collection techniques used were observation with the observation sheet instruments that equipped with assessment guide lines and photographs as documentation, while the techniques of data analysis performed quantitative descriptive. The results of this study showed an increase in the quality of social learning. Comparison cognitive skills of students at the pre-cycle only 38\%, whereas at the end of first cycle have 68,75\%, and at the end second cycle there were 93,75\%. While comparison interest learn students at the pre-cycle is $32,25 \%$, first cycle is $82 \%$ and at the end second cycle there were $93,75 \%$.

Keywords: game of domino, social lesson, cognitive ability, interest of learning
\end{abstract}

\begin{abstract}
ABSTRAK
Dalam pembelajaran di sekolah guru memegang peranan penting untuk menciptakan lingkungan belajar yang dapat merangsang potensi siswa agar dapat berkembang dengan maksimal. Penelitian ini menggunakan rancangan Penelitian Tindakan Kelas yang dilakukan dengan dua siklus. Teknik pengumpulan data yang digunakan adalah observasi dengan instrumen lembar observasi yang dilengkapi dengan pedoman penilaian serta dokumentasi berupa foto, sedangkan teknik analisis data dilakukan secara deskriptif kuantitatif. Hasil penelitian ini menunjukkan adanya peningkatan kualitas pembelajaran IPS. Perbandingan kemampuan kognitif siswa pada tahap pra siklus hanya $38 \%$, pada akhir siklus I sebesar $68,75 \%$, pada akhir siklus II sebesar 93,75\%. Sedangkan perbandingan minat belajar siswa pada tahap pra siklus adalah $32,25 \%$, siklus I adalah $82 \%$ sedangkan pada akhir siklus II naik menjadi 93,75\%.

Kata Kunci: Permainan Domino, Pelajaran IPS, Kemampuan Kognitif, minat belajar
\end{abstract}




\section{A. PENDAHULUAN}

Pendidikan Ilmu Pengetahuan Sosial (PIPS) merupakan satu bidang studi yang dipelajari pada pendidikan Sekolah Dasar. Bidang studi ini menerapkan pendekatan interdisipliner, baik dalam mendesain kurikulum maupun dalam rangka penyampaiannya kepada para siswa. Bidang studi ini merupakan pelajaran yang penting bagi kehidupan siswa di masa datang. Sebagai mata pelajaran yang syarat dengan pengetahuan sosial ini banyak memiliki kontribusi bagi siswa sebagai tunas bangsa dalam membentuk diri menjadi warga negara yang tangguh dan berbudaya tinggi.

Pendidikan IPS secara global mempunyai tujuan tertentu yang akan dicapai oleh peserta didik dalam kegiatan belajar mengajar di kelas. Tujuan mata pelajaran PIPS ada tiga macam: (1) pendidikan kemanusiaan yang membantu peserta didik memahami pengalamannnya dan bermanfaat dalam kehidupan, (2) pendidikan kewarganegaraan, dan (3) pendidikan intelektual (Soewarso, 2000: 223).
Namun proses pembelajaran Ilmu Pengetahuan Sosial masih mengalami kendala. Selama pembelajaran berlangsung siswa terkesan tidak memperhatikan penjelasan guru, bahkan diantaranya ada yang bermain-main, memperhatikan suasana lain di luar kelas, melamun, ataupun mengantuk. Pada saat guru memberikan pertanyaan, umumnya siswa tidak merespon apalagi menjawab pertanyaan guru, bahkan guru sering menjawab pertanyaannya sendiri. Demikian pula, ditemukan adanya kelemahan guru dalam pembelajaran klasikal, misalnya guru kurang memperhatikan relevansi bahan yang disampaikan dengan kebutuhan hidup anak di masyarakat, lebih bersifat transfer of knowlege, kurang bermakna bagi anak didik dalam menambah pengalaman belajar (Nina Kurniah, 1998: 85). Kelemahan penguasaan bidang studi oleh guru berkaitan dengan lemahnya penguasaan guru mengenai isi kurikulum, baik itu berkenaan ruang lingkup maupun urutan. Selain itu kelemahan terjadi berkaitan dengan cara guru menguasai bidang studi 
(Freema Elbaz dalam Nina Kurniah, 1998: 85).

Menyikapi permasalahan yang demikian, di zaman sekarang ini guru dituntut untuk kreatif di segala macam pembelajaran. Bentuk kreativitas guru dapat dilakukan dengan mengadakan variasi pembelajaran. Soetomo (dalam Majid, 2013: 262) menyatakan bahwa variasi dalam proses pembelajaran dapat diartikan sebagai perubahan cara penyampaian yang satu ke cara penyampaian yang lain dengan tujuan menghilangkan kebosanan atau kejenuhan siswa saat belajar sehingga menjadi aktif berpartisipasi dalam belajaranya.

Pada dasarnya anak-anak sebagai generasi yang unggul tidak akan tumbuh dengan sendirinya. Dalam pembelajaran di sekolah guru memegang peranan penting untuk menciptakan lingkungan belajar yang dapat merangsang potensi siswa agar dapat berkembang dengan maksimal. Perkembangan berkenaan dengan keseluruhan kepribadian individu anak, karena kepribadian individu membentuk satu kesatuan yang terintegrasi. Secara umum dapat dibedakan beberapa aspek utama kepribadian individu anak yaitu aspek (1) kognitif, (2) fisik-motorik, (3) sosio-emosional, (4) bahasa, (5) moral dan (6) keagamaan. Budiningsih (2005: 34) menyatakan bahwa kognitif merupakan suatu proses internal yang mencakup ingatan, retensi, pengolahan informasi, emosi dan aspek-aspek kejiwaan lainnya. Dalam hal ini belajar merupakan aktifitas yang melibatkan proses berfikir yang sangat kompleks.

Menurut Piaget, dinamika perkembangan intelektual individu mengikuti dua proses, yaitu asimilasi dan akomodasi. Asimilasi adalah proses kognitif di mana seseorang mengintegrasikan persepsi, konsep atau pengalaman baru ke dalam struktur kognitif yang sudah ada di dalam pikirannya. Sedangkan akomodasi adalah proses perubahan struktur kognitif sehingga dapat dipahami. Dengan kata lain apabila individu menerima informasi atau pengalaman baru maka informasi tersebut akan dimodifikasi sehingga cocok dengan struktur kognitif yang telah dipunyainya (Budiningsih, 
2005:35). Ada dua macam fungsi guru SD yang berkaitan dengan proses asimilasi yaitu meletakkan dasar struktur kognitif yang tepat tentang sesuatu konsep pada kognisi anak memperkaya struktur kognitif menjadi semakin lengkap dan mendalam. Kognitif perkembanganya diawali dengan perkembangan kemampuan mengamati, melihat hubungan dan memecahkan masalah sederhana. Kemudian berkembang ke arah pemahaman dan pemecahan masalah yang lebih rumit.

Berdasarkan penjabaran di atas aspek kognitif di rasa sangat penting untuk diteliti. Aspek kognitif ini berkembang pesat pada masa anak mulai masuk sekolah dasar (6-7 tahun). Berkembang konstan selama masa belajar dan mencapai puncaknya pada masa sekolah menengah atas (usia 16-17 tahun). Selain ranah kognitif, dalam penelitian ini juga akan dibahas tentang ranah afektif siswa yaitu tentang minat belajar siswa dalam pelajaran IPS. Peneliti mengambil penelitian di kelas V SDN Kemuning pada pelajaran IPS khususnya materi peristiwa sekitar Proklamasi
Kemerdekaan. Salah satu kendala dalam pembelajaran IPS biasanya disebabkan karena materi pelajaran IPS itu identik dengan hafalan. Sehingga siswa merasa kurang semangat dalam belajar. Minat belajar siswa terhadap pelajaran IPS juga rendah. Keadaan yang demikian perlu diperbaiki, jika minat belajar siswa terhadap pelajaran IPS meningkat, diharapkan kemampuan kognitif siswa pada pelajaran IPS juga meningkat.

Jean Peaget dalam (Ruseffendi, 1992:143) berpendapat bahwa siswa yang tahap berpikirnya masih ada pada tahap operasional konkrit tersebar umur dari sekitar 7 tahun sampai sekitar 11, 12 atau atau 13 tahun kadang-kadang lebih. Mengingat karakteristik siswa SD yang masih berada pada tahap berfikir operasional konkret, maka perlu adanya bantuan media pembelajaran dalam proses pembelajaran. Media yang digunakan dalam pembelajaran di sini adalah kartu domino yang telah dimodifikasi dengan materi pelajaran IPS SD kelas V yaitu materi peristiwa sekitar proklamasi kemerdekaan. Kartu tersebut dikemas dalam 
permainan domino yang sudah dikenal oleh anak sehingga anak akan lebih antusias dalam kegiatan bermain yang di dalamnya mengandung unsur pembelajaran ini. Dan tentu saja karena pembelajaran IPS ini dilakukan dengan permainan, maka anak akan merasa lebih senang dan tidak terbebani.

Berdasarkan uraian di atas, peneliti merumuskan dua macam rumusan masalah yaitu

Bagaimanakah penerapan permainan domino untuk meningkatkan kemampuan kognitif dan minat belajar siswa kelas $\mathrm{V}$ di SDN Kemuning? (2) Apakah penerapan permainan domino dapat meningkatkan kemampuan kognitif siswa kelas V di SDN Kemuning? (3) Apakah penerapan permainan domino dapat meningkatkan minat belajar siswa kelas $\mathrm{V}$ di SDN Kemuning? Tujuan penelitian ini yaitu (1) untuk mengetahui penerapan permainan domino dalam meningkatkan kemampuan kognitif dan minat belajar siswa kelas $\mathrm{V}$ di SDN Kemuning, (2) Untuk mengetahui peningkatan kemampuan kognitif siswa kelas $\mathrm{V}$ di SDN
Kemuning melalui penerapan permainan domino, (3) Untuk mengetahui peningkatan minat belajar siswa kelas $\mathrm{V}$ di SDN Kemuning melalui penerapan permainan domino.

Penelitian ini diharapkan dapat bermanfaat bagi berbagai pihak, yaitu: Siswa (melalui penelitian ini diharapkan siswa dapat meningkatkan kemampuan kognitif serta minat belajarnya agar menjadi generasi yang kompeten di bidangnya); Guru (diharapkan guru agar kreatif di segala macam pembelajaran sehingga siswa akan lebih mudah dalam memahami materi pelajaran); Peneliti (melalui penulisan penelitian ini, peneliti mendapat tambahan pengetahuan, pengalaman mengenai dunia pendidikan dan saat ini dan memacu peneliti untuk lebih belajar lagi); Pembaca (melalui penelitian ini diharapkan dapat menambah pengetahuan tentang dunia pendidikan di Indonesia pada umumnya dan di Kabupaten Ponorogo khususnya).

\section{B. METODE PENELITIAN}


Jenis penelitian yang akan digunakan dalam penelitian ini adalah Penelitian Tindakan Kelas (PTK) yang menggunakan pendekatan deskriptif kuantitatif dan kualitatif. Model pelaksanaan penelitian tindakan kelas yang digunakan adalah model penelitian tindakan kelas yang dilaksanakan secara kolaboratif. Penelitian ini bertujuan untuk memperbaiki kualitas pembelajaran dan meningkatkan hasil belajar anak didik.

Kegiatan penelitian ini dilakukan dengan alur pokok (siklus) sebagai berikut: planning (perencanaan), acting\&observing (tindakan dan pengamatan), reflecting (perefleksian), dan revise plan (perbaikan rencana). Jika hasil refleksi menunjukkan perlu dilakukan perbaikan atas tindakan yang dilakukan, maka rencana tindakan perlu disempurnakan kembali agar tindakan berikutnya bukan sekedar mengulang yang telah dilakukan sebelumnya

Subyek penelitian adalah siswa kelas V di SDN Kemuning dengan jumlah 16 siswa yang terdiri dari 8 laki-laki dan 8 perempuan.
Teknik pengumpulan data yang digunakan adalah observasi dengan instrumen lembar observasi yang dilengkapi dengan pedoman penilaian serta dokumentasi berupa foto, sedangkan teknik analisis data dilakukan secara deskriptif kuantitatif.

Analisis data dilakukan setiap satu siklus berakhir. Analisis data penilitian tindakan kelas ini adalah deskriptif kualitatif dan kuantitatif. Analisis deskripsi kuantitatif digunakan untuk mengolah data kemampuan kognitif anak melalui permainan domino dalam pembelajaran yang didapat di lapangan. Analisis deskripsi kualitatif digunakan untuk mengolah data aktivitas guru dan anak serta dokumentasi penelitian.

Keberhasilan penelitian ini ditentukan dengan cara menghitung jumlah skor yang diperoleh anak yang merupakan indikator pencapaian kesiapan perkembangan individu dan dapat dipergunakan untuk mengetahui kesiapan perkembangan pembelajaran secara klasikal. Indikator keberhasilan diperlukan untuk mengetahui tingkat 
keberhasilan penelitian yang tersebut, menentukan indikator yang digunakan sebagai pedoman kapan hendak dicapai, menjabarkan penelitian ini bisa diakhiri yaitu ketika penelitian sudah dikatakan berhasil atau mampu meningkatkan kesiapan perkembangan dengan kriteria sebagai berikut:

1. Secara perorangan (individu) dianggap telah memiliki kesiapan perkembangan

apabila kemampuan kognitif dan minat belajar siswa termasuk dalam kualifikasi baik

indikator kemampuan kognitif, menjabarkan indikator minat belajar siswa yang akan digunakan dalam kegiatan belajar mengajar yaitu melalui permainan domino, merumuskan kegiatan pembelajaran, menentukan media pembelajaran berupa gambar tokoh-tokoh yang terlibat dalam peristiwa sekitar proklamasi kemerdekaan Indonesia dan kartu domino, menentukan 2. Secara klasikal (kelas) pembelajaran dianggap telah berhasil apabila siswa yang berkemampuan kognitif dengan kualifikasi baik dan sangat baik lebih dari $75 \%$ dari jumlah seluruh anak di kelas.

Dalam penelitian ini direncanakan dilakukan dua siklus yaitu siklus I dan siklus II. Siklus I direncanakan dalam satu kali pertemuan yang berlangsung selama 2x35 menit. Rencana pembelajaran dititikberatkan pada bidang pengembangan kognitif dan minat belajar siswa. Adapun rencana siklus 1 adalah menentukan tema yang sesuai dengan jadwal di sekolah pengelolaan kelas, menyusun alat pengumpulan data yang berupa lembar observasi dan dokumentasi sebagai bahan penyusunan rencana pengolahan data.

Pelaksanaan kegiatan belajar sesuai dengan Rencana Pelaksanaan Pembelajaran (RPP) pada hari yang ditentukan. Selama tahap pelaksanaan peneliti dibantu kolaborator melakukan observasi terhadap kemampuan anak dalam permainan domino serta aspek perkembangan lain yang diharapkan bisa dikembangkan dengan permainan ini dengan menggunakan lembar observasi yang telah disiapkan. Pada tahap penilaian, kegiatan observasi 
dapat dilakukan kolaborasi dengan teman sejawat. Dalam permainan domino aspek utama yang dinilai adalah kemampuan anak dalam mencocokkan gambar dan nama tokoh dengan menyebutkan peranannya dalam peristiwa sekitar proklamasi.

Dari hasil pengamatan peneliti pada siklus 1, dilakukan analisis data bersama kolaborator yang membantu dalam kegiatan ini guna mengetahui peningkatan kemampuan kognitif dan minat belajar siswa dalam pembelajaran IPS melalui kegiatan belajar mengajar yang telah dilaksanakan menggunakan permainan domino. Hasil yang diperoleh dan permasalahan yang muncul di siklus I merupakan dasar untuk melakukan rancangan ulang siklus II.

\section{HASIL PENELITIAN}

1. Kemampuan Kognitif Siswa

Berdasarkan data-data dari pra siklus, siklus I dan siklus II maka peningkatan kemampuan kognitif siswa dapat digambarkan dalam grafik sebagai berikut:

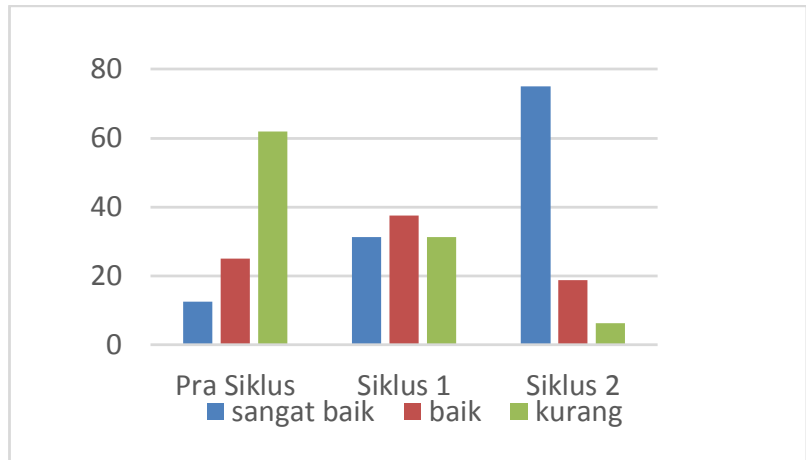

\section{Gambar 1. Kemampuan kognitif siswa kelas V di SDN Kemuning pada pra siklus, setelah siklus I dan siklus II}

Gambar 1 menunjukkan bahwa pada pra siklus kemampuan kognitif anak dalam pelajaran IPS siswa kelas V di SDN Kemuning dari 16 anak hanya 2 anak $(12,5 \%)$ mempunyai kemampuan kognitif tentang pelajaran IPS dengan kualifikasi sangat baik, 4 anak (25\%) mempunyai kemampuan dengan kualifikasi baik, 10 anak $(62,5 \%)$ mempunyai kemampuan dengan kualifikasi kurang. Sedangkan pada akhir siklus I, 5 anak $(31,25 \%)$ mempunyai kemampuan dengan kualifikasi sangat baik, 6 anak (37,5\%) anak mempunyai kemampuan dengan kualifikasi baik, 5 anak $(31,25 \%)$ mempunyai kemampuan dengan kualifikasi kurang. Pada akhir siklus II, 12 anak (75\%) mempunyai kemampuan 
dengan kualifikasi sangat baik, 3 anak $(18,75 \%)$ mempunyai kemampuan dengan kualifikasi baik, dan 1 anak $(6,25 \%)$ mempunyai berkualifikasi kurang.

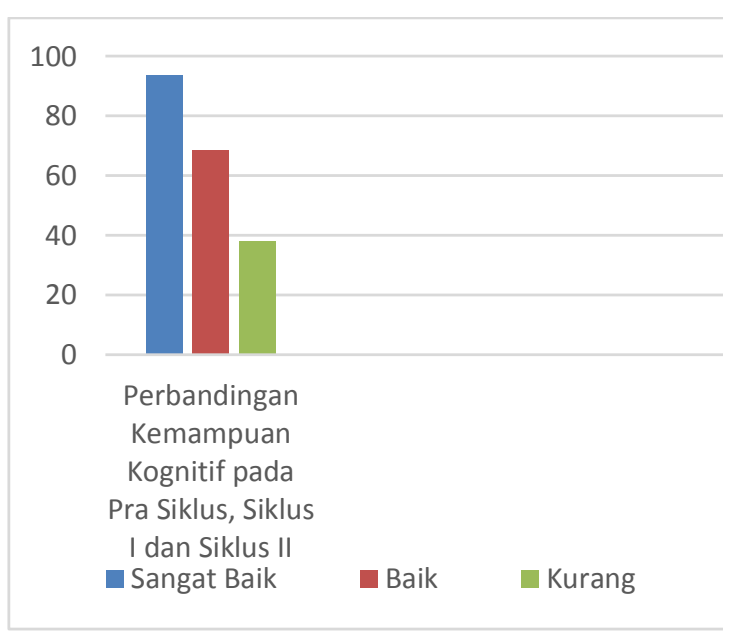

Gambar 2. Perbandingan Kemampuan Kognitif Secara Klasikal Pada Pra Siklus, Siklus I dan Siklus II

Dari gambar 2 di atas dapat diketahui bahwa kemampuan kognitif secara klasikal pada pra siklus adalah $38 \%, \quad$ siklus I adalah $68,75 \%$ sedangkan pada akhir siklus II naik menjadi $93,75 \%$.

\section{Minat Belajar Siswa}

Berdasarkan data-data dari pra siklus, siklus I dan siklus II maka peningkatan minat belajar siswa dapat digambarkan dalam grafik sebagai berikut:

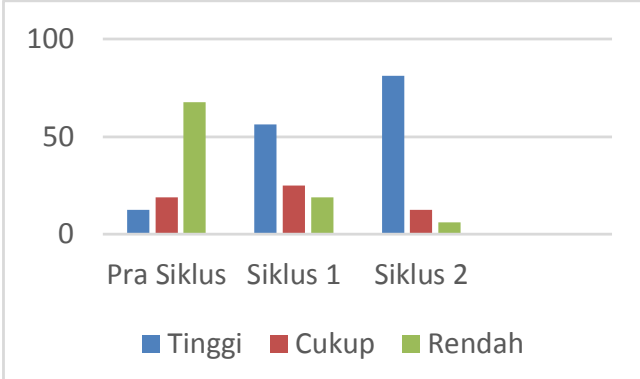

Gambar 3. Minat belajar siswa kelas V di SDN Kemuning pada pra siklus, setelah siklus I dan siklus II

Gambar 3 menunjukkan bahwa pada pra siklus minat belajar siswa dalam pelajaran IPS siswa kelas $\mathrm{V}$ di SDN Kemuning dari 16 anak hanya 2 anak (12,5\%) mempunyai minat belajar IPS dengan kualifikasi tinggi, 3 anak $(18,75 \%)$ mempunyai kemampuan dengan kualifikasi cukup, 11 anak $(67,75 \%)$ mempunyai minat belajar dengan kualifikasi kurang. Sedangkan pada akhir siklus I, 9 anak (56,25\%) mempunyai minat belajar dengan kualifikasi tinggi, 4 anak $(25 \%)$ anak mempunyai minat belajar dengan kualifikasi cukup, 3 anak (18\%) mempunyai minat belajar dengan kualifikasi kurang. Pada akhir siklus II, 13 anak (81,25\%) mempunyai minat belajar dengan kualifikasi tinggi, 2 anak (12,5\%) mempunyai minat belajar dengan kualifikasi cukup, dan 1 anak (6,25\%) 
mempunyai minat belajar dengan kualifikasi kurang.

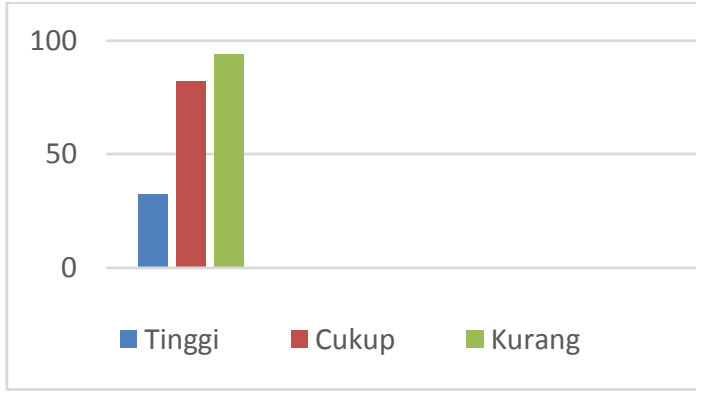

Gambar 4. Perbandingan Minat Belajar Pada Pra Siklus, Siklus I dan Siklus II

Dari gambar 4 di atas dapat diketahui bahwa minat belajar siswa pada tahap pra siklus adalah $32,25 \%$, siklus I adalah $82 \%$ sedangkan pada akhir siklus II naik menjadi 93,75\%.

\section{PEMBAHASAN}

1. Penerapan Permainan Domino untuk Meningkatkan Kemampuan Kognitif dan Minat Belajar Siswa Kelas V di SDN Kemuning, Kecamatan Sambit, Kabupaten Ponorogo Tujuan aspek kognitif berorientasi pada kemampuan berfikir yang mencakup kemampuan intelektual yang lebih sederhana yaitu mengingat, sampai pada kemampuan memecahkan masalah yang menuntut siswa untuk menghubungkan dan menggabungkan beberapa ide, gagasan, metode, atau prosedur yang dipelajari untuk memecahkan masalah tersebut (Slameto, 2003: 114). Berkaitan dengan pendapat tersebut, penerapan permainan domino dalam pembelajaran IPS kelas V di SDN Kemuning ini menggunakan media kartu domino yang sebelumnya telah dimodifikasi menyesuaikan materi pelajaran yaitu tentang peristiwa sekitar proklamasi. Permainan Domino diterapkan melalui dua siklus penelitian sehingga dapat diketahui adanya perubahan kemampuan kognitif dan minat belajar siswa dalam pembelajaran IPS sebagai dampaknya. Kemampuan kognitif yang diharapkan bisa meningkat dengan permainan ini adalah anak dapat menyebutkan nama tokoh yang dan peranannya dalam peristiwa sekitar proklamasi kemerdekaan. Selain perkembangan kognitif, permainan ini diharapkan mampu membantu meningkatkan minat belajar siswa terhadap pelajaran IPS. Minat belajar ini yang dapat diketahui di setiap akhir siklus melalui pengamatan terhadap siswa berdasarkan pedoman observasi yang telah ditentukan sebelumnya. 
Langkah-langkah permainan domino ini adalah:

a. Anak dibagi menjadi kelompok yang beranggotakan 4 anak

b. Anak dikondisikan duduk melingkar agar bisa saling berhadapan

c. Guru menjelaskan aturan main domino

d. Guru memberikan kartu domino yang berjumlah 16 buah kepada kelompok

e. Guru meminta salah satu anak untuk mengocok kartu dan membagikannya secara rata sehingga setiap anak mendapat 4 kartu, namun jika anak kesulitan guru bisa menggantikan mengocok dan membagi kartu

f. Guru memberi waktu 30 menit untuk anak memainkan permainan domino sampai selesai sesuai dengan aturan sebagai berikut:

1) Kartu pertama yang dibuka adalah kartu 1:1

2) Setelah itu anak yang bermain adalah yang berada di sebelah kanannya

3) Jika anak yang waktunya bermain tidak mempunyai kartu, maka dilanjutkan oleh teman di sebelah kanannya lagi sampai kartu habis

4) Pemain yang menang adalah pemain yang kartunya habis pertama. Permainan ini menitik beratkan pada proses pembelajaran yang menarik dan menyenangkan bagi anak. Pada siklus I permainan berlangsung kurang kondusif karena permainan domino merupakan permainan yang baru untuk anak. Penjelasan guru yang terlalu cepat dan kegaduhan yang dilakukan oleh anak yang tidak sedang bermain mengakibatkan banyak pertanyaan yang sama ketika permainan sedang berlangsung. Dalam siklus I pada kegiatan menyebutkan nama tokoh dan peranannya dalam proklamasi kemerdekaan, masih ada anak yang kurang aktif dan kurang percaya diri. Ada anak yang hanya tersenyum menatap guru dan tidak mau membuka suara, ada juga yang membilang dengan suara yang lemah.

Pada siklus II permainan berlangsung lebih kondusif. Anak sudah memahami aturan permainan domino dan guru sudah memperbaiki 
cara memberikan penjelasan kepada anak. Kegaduhan juga bisa diatasi dengan membagi kelas menjadi tiga kelompok kecil dengan tiga kegiatan yang berbeda sehingga guru mampu fokus pada permainan domino. Dalam siklus ini banyak terjadi peningkatan kualitas anak ketika menyebutkan nama tokoh serta perananya dalam proklamasi kemerdekaan. Dalam menjawab anak juga sudah mendapatkan percaya dirinya sehingga lebih aktif dalam permainan. Anak-anak juga mulai kritis dan teliti ketika temannya melakukan kesalahan.

\section{Peningkatan}

Kemampuan

Kognitif Siswa Kelas V pada Pelajaran IPS di SDN Kemuning Kecamatan Sambit Kabupaten Ponorogo

Permainan Domino yang dilakukan dalam dua siklus ini telah dapat meningkatkan kemampuan kognitif siswa Kelas V pada pelajaran IPS di SDN Kemuning, Kecamatan Sambit, Kabupaten Ponorogo. Hal ini dibuktikan dengan data yang diperoleh pada pra siklus, kemampuan kognitif anak dalam pelajaran IPS menunjukkan dari 16 siswa hanya 2 siswa $(12,5 \%)$ mempunyai kemampuan kognitif dengan kualifikasi sangat baik, 4 siswa (25\%) mempunyai kemampuan kognitif dengan kualifikasi baik, 10 siswa (62\%) mempunyai kemampuan kognitif dengan kualifikasi kurang. Sedangkan pada akhir siklus I, 5 siswa $(31,25 \%)$ mempunyai kemampuan kognitif dengan kualifikasi sangat baik, 6 siswa $(37,5 \%)$ mempunyai kemampuan kognitif dengan kualifikasi baik, 5 siswa $(31,25 \%)$ mempunyai kemampuan kognitif dengan kualifikasi kurang. Pada akhir siklus II, 12 siswa (75\%) mempunyai kemampuan kognitif dengan kualifikasi sangat baik, 3 siswa $(18,75 \%)$ mempunyai kemampuan kognitif dengan kualifikasi baik, dan 1 siswa $(6,25 \%)$ mempunyai kemampuan kognitif dengan kualifikasi kurang.

Uraian di atas sesuai dengan pendapat Plato, Aristoteles, dan Frobel bahwa bermain sebagai kegiatan yang mempunyai nilai praktis, artinya bermain digunakan sebagai media untuk meningkatkan ketrampilan dan kemampuan tertentu 
pada anak (Sugianto, 2005: 4) sedangkan menurut teori Lev Vigotsky bermain akan membantu perkembangan bahasa dan berfikir (Sugianto, 2005: 4). Permainan dengan stimulasi tertentu di dalamnya maka akan meningkatkan kemampuan tertentu bagi yang bermain. Dengan menggunakan permainan domino sebagai alat bantu, anak diharapkan mampu memahami materi dalam pelajaran IPS dalam hal ini adalah materi tentang peristiwa sekitar proklamasi kemerdekaan, di mana banyak memuat nama tokoh, tahun dan tanggal penting serta peristiwa yang susah diingat jika tidak menggunakan alat bantu berupa media ataupun metode bermain sambil belajar.

Para ahli pendidikan seperti Gutsmuths, Montessori dan Frobel menyatakan bahwa permainan hendaknya menjadi alat pendidikan yang utama untuk menuntun pertumbuhan jasmani dan rohani dengan kegunaan untuk menumbuhkan sifat sosial, mengembangkan fantasi, bakat dan kreasi, mendatangkan perasaan senang menumbuhkan rasa tanggung jawab dan disiplin karena anak harus menaati peraturan- peraturan (Pontjopoetro, 2006: 1.12). Seperti halnya permainan domino ini juga digunakan sebagai alat pendidikan untuk mengembangkan kemampuan kognitif serta rasa tanggung jawab, sabar, disiplin, dan kesopanan dalam berbicara yang tentu saja sangat berguna untuk kehidupan sosialnya ketika bergaul dengan orang lain di sekitarnya dan dalam masyarakat.

Menurut Bruner, teori perkembangan kognitif seseorang terjadi melalui tiga tahap yang ditentukan oleh caranya melihat lingkungan, yaitu enactive, iconic dan symbolic.

a. Tahap enaktif, seseorang melakukan aktivitas-aktivitas dalam upayanya untuk memahami lingkungan sekitarnya. Artinya, dalam memahami dunia sekitarnya anak menggunakan pengetahuan motorik. Misalnya melalui gigitan, sentuhan, pegangan dan sebagainya.

b. Tahap ikonik, seseorang memahami objek-objek atau dunianya melalui gambar-gambar dan visualisasi verbal. Maksudnya, 
dalam memahami dunia sekitarnya anak belajar melalui bentuk perumpamaan (tampil) dan perbandingan (komparasi).

c. Tahap simbolik, seseorang telah mampu memiliki ide-ide atau gagasan-gagasan abstrak yang sangat dipengaruhi oleh kemampuannya dalam berbahasa dan logika. Dalam memahami dunia sekitarnya anak belajar melalui simbol-simbol bahasa, logika, matematika dan sebagainya.

Berdasarkan teori tersebut permainan domino yang dimodifikasi ke dalam materi pelajaran IPS telah sesuai. Pada tahap enaktif, siswa melakukan serangkaian aktifitas dalam permainan domino untuk mempermudah mereka memahami materi peristiwa sekitar proklamasi. Pada tahap ikonik, dalam kartu domino telah disertai gambar-gambar tokoh yang terlibat dalam peristiwa sekitar proklamasi kemerdekaan. Tahap simbolik, gambar-gambar yang disertakan pada kartu domino memiliki karakter-karakter yang berbeda sehingga dapat digunakan sebagai simbol yang membedakan antara satu dengan yang lain.

Selain pendapat tersebut Jean Piaget dalam Slameto (2003: 115116) juga menyatakan bahwa perkembangan kognitif seorang anak terjadi secara bertahap. Teori tersebut sangat sesuai dengan perkembangan kognitif anak melalui permainan domino di SDN Kemuning, Kecamatan Sambit, Kabupaten Ponorogo. Pada siklus I kemampuan kognitif anak meningkat jika dibandingkan dengan pra siklus dan mengalami peningkatan lagi pada akhir siklus II. Hal tersebut disebabkan daya kognisi anak yang distimulasi terus menerus sehingga meningkat secara bertahap sesuai dengan frekuensi stimulasi yang diberikan.

3. Peningkatan Minat Belajar Siswa Kelas V pada Pelajaran IPS di SDN Kemuning Kecamatan Sambit Kabupaten Ponorogo Menurut Slameto (2003:180) minat adalah suatu rasa lebih suka dan rasa ketertarikan pada suatu hal atau aktivitas tanpa ada yang menyuruh. Menurut Singgih (2004:131) mengatakaan bahwa munculnya 
minat yaitu dalam bentuk perhatian dan keinginan. Menurut Sugiyanto (2001:4.32) minat untuk melakukan aktivitas fisik sangat dipengaruhi oleh kesempatan untuk melakukan aktivitas fisik itu sendiri. Apabila sejak kecil anak selalu dikekang atau tidak diberi kesempatan melakukan aktivitas itu akan tidak berkembang.

Dalam penelitian ini, permainan domino yang dilakukan dalam dua siklus ini telah dapat meningkatkan minat belajar siswa Kelas V pada pelajaran IPS di SDN Kemuning, Kecamatan Sambit, Kabupaten Ponorogo. Hal ini dibuktikan dengan data yang diperoleh pada pra siklus, minat belajar anak dalam pelajaran IPS menunjukkan dari 16 siswa hanya 2 siswa $(12,5 \%)$ mempunyai minat belajar IPS dengan kualifikasi tinggi, 3 anak (18,75\%) mempunyai kemampuan dengan kualifikasi cukup, 11 anak $(67,75 \%)$ mempunyai minat belajar dengan kualifikasi kurang. Sedangkan pada akhir siklus I, 9 anak $(56,25 \%)$ mempunyai minat belajar dengan kualifikasi tinggi, 4 anak $(25 \%)$ anak mempunyai minat belajar dengan kualifikasi cukup, 3 anak (18\%) mempunyai minat belajar dengan kualifikasi kurang. Pada akhir siklus II, 13 anak (81,25\%) mempunyai minat belajar dengan kualifikasi tinggi, 2 anak (12,5\%) mempunyai minat belajar dengan kualifikasi cukup, dan 1 anak (6,25\%) mempunyai minat belajar dengan kualifikasi kurang.

Melalui permainan domino dalam pembelajaran IPS di kelas V siswa menjadi mempunyai kecenderungan untuk lebih memperhatikan dan mengenang beberapa aktifitas atau kegiatan yang dilakukan, hal ini muncul dikarenakan oleh adanya tanggapan atau rangsangan untuk melakukan suatu aktivitas tersebut.

Siswa yang memiliki minat terhadap subjek tertentu cenderung untuk memberikan perhatian yang lebih besar.

Penelitian ini menunjukkan bahwa minat adalah perasaan seseorang yang dapat mendorong siswa untuk melakukan sesuatu yang diawali dengan memperhatikan suatu objek, keinginan untuk terlibat langsung dalam aktivitas tersebut dan kesempatan untuk melakukan 
sesuatu. Minat yang ada dalam diri seseorang merupakan salah satu faktor untuk memecahkan suatu masalah, yaitu sikap yang membuat orang menjadi senang akan suatu objek, sedangkan faktor-faktor yang penting yang dapat menyebabkan timbulnya minat tersebut adalah kesempatan untuk melakukan aktifitas fisik itu sendiri, perhatian, rasa tertarik, rasa senang, keinginan untuk terlibat langsung dalam aktivitas dan faktor lain yang mempengaruhi timbulnya minat.

\section{E. SIMPULAN}

Berdasarkan hasil penelitian tentang penerapan permainan dominountuk meningkatkan kemampuan kognitif siswa kelas V pada pelajaran IPS di SDN Kemuning, maka dapat disimpulkan bahwa:

1. Penerapan permainan domino dilakukan melalui proses pembelajaran yang melibatkan anak secara aktif dalam permainan yang menyenangkan untuk memahami materi peristiwa sekitar proklamasi kemerdekaan dengan langkah-langkah sebagai berikut, anak dibagi menjadi kelompok yang beranggotakan 4 anak, anak dikondisikan duduk melingkar agar bisa saling berhadapan, guru menjelaskan aturan main domino, guru memberikan kartu domino yang berjumlah 16 buah kepada kelompok, guru meminta salah satu anak untuk mengocok kartu dan membagikannya secara rata sehingga setiap anak mendapat 4 kartu, namun jika anak kesulitan guru bisa menggantikan mengocok dan membagi kartu, guru memberi waktu pada anak memainkan permainan domino sampai selesai.

2. Penerapan permainan domino dapat meningkatkan kemampuan kognitif tentang pelajaran IPS khususnya materi peristiwa sekitar proklamasi. Dalam kegiatan pra siklus, data menunjukkan dari 16 siswa hanya $12,5 \%$ anak mempunyai kemampuan kognitif dengan kualifikasi sangat baik, $25 \%$ anak mempunyai kemampuan kognitif dengan kualifikasi baik, $62 \%$ anak 
mempunyai kemampuan kognitif dengan kualifikasi kurang. Sedangkan pada akhir siklus I, $31,25 \%$ anak mempunyai kemampuan kognitif dengan kualifikasi sangat baik, 37,5\% anak mempunyai kemampuan kognitif dengan kualifikasi baik, $31,25 \%$ anak mempunyai kemampuan kognitif dengan kualifikasi kurang. Pada akhir siklus II, 75\% anak mempunyai kemampuan kognitif dengan kualifikasi sangat baik, $18,75 \%$ anak mempunyai kemampuan kognitif dengan kualifikasi baik, dan 6,25\% anak mempunyai kemampuan kognitif dengan kualifikasi kurang. Sedangkan keberhasilan pembelajaran secara klasikal untuk kemampuan kognitif mengalami peningkatan dari siklus I yaitu $68,75 \%$ meningkat pada akhir siklus II menjadi $93,75 \%$, sehingga tindakan menggunakan permainan domino ini bisa dihentikan dan dianggap berhasil dengan kualifikasi sangat baik.

3. Penerapan permainan domino dapat meningkatkan minat belajar siswa kelas $\mathrm{V}$ dalam pelajaran IPS. Hal itu dibuktikan dari 16 siswa hanya 2 siswa $(12,5 \%)$ mempunyai minat belajar IPS dengan kualifikasi tinggi, 3 anak (18,75\%) mempunyai kemampuan dengan kualifikasi cukup, 11 anak $(67,75 \%)$ mempunyai minat belajar dengan kualifikasi kurang. Sedangkan pada akhir siklus I, 9 anak $(56,25 \%)$ mempunyai minat belajar dengan kualifikasi tinggi, 4 anak (25\%) anak mempunyai minat belajar dengan kualifikasi cukup, 3 anak (18\%) mempunyai minat belajar dengan kualifikasi kurang. Pada akhir siklus II, 13 anak $(81,25 \%)$ mempunyai minat belajar dengan kualifikasi tinggi, 2 anak (12,5\%) mempunyai minat belajar dengan kualifikasi cukup, dan 1 anak $(6,25 \%)$ mempunyai minat belajar dengan kualifikasi kurang.

\section{F. SARAN}

1. Guru SD diharapkan dapat menerapkan permainan domino secara efektif untuk memecahkan masalah rendahnya kualitas 
proses pembelajaran seperti guru yang terlalu banyak menggunakan metode ceramah atau tidak menggunakan media pembelajaran dan rendahnya kemampuan kognitif anak dalam memahami materi pelajaran IPS. Metode yang diterapkan pada penelitian ini dapat dicobakan untuk memecahkan masalah pembelajaran lainnya dengan cara yang menyenangkan untuk anak.

2. Pihak sekolah, ketika menentukan kebijakan untuk mengubah pembelajaran yang berpusat pada guru menjadi berpusat pada anak dan sebagai bentuk inovasi baru dalam pembelajaran konsep berhitung dengan menggunakan modelmodel permainan yang tentunya lebih disukai anak dan dengan hal tersebut diharapkan pembelajaran lebih bermakna untuk anak.

3. Lebih lanjut disarankan agar dilakukan penelitian lanjutan tentang permainan domino baik dari cara bermain yang lebih inovatif, aturan permainan, pengaturan waktu, frekuensi bermain, maupun pemilihan operasi hitung harus disesuaikan dengan masa peka atau kesiapan anak, suasana hati anak yang mudah berubah atau cepat bosan serta perlu dipertimbangankan agar permainan ini dapat mengembangkan tidak hanya kemampuan kognitif anak saja tetapi kemampuan-kemampuan yang lain.

\section{DAFTAR PUSTAKA}

Arikunto, Suharsimi. 2009. DasarDasar Evaluasi Pendidikan (Edisi Revisi). Jakarta: Bumi Aksara

Buddiningsih, Asri. 2005. Belajar dan Pembelajaran. Jakarta: Rineka Cipta.

Kurniah, Nina. 1998. Penerapan Pembelajaran Terpadu Dalam Mata Pelajaran Ilmu Pengetahuan Sosial (IPS) di Kelas 3 dan 4 SD No. 70 Kodia Bengkulu. Jurnal Penelitian Pendidikan Dasar. Nomor 6 Tahun II 1998. Jakarta: Depdikbud.

Majid, Abdul. 2013. Strategi Pembelajaran. Bandung: Rosda Karya.

Pontjopoetro, dkk. 2006. Permainan Anak, Tradisional dan 
Aktivitas Ritmik. Jakarta: Universitas Terbuka

Ruseffendi, E.T. 1998. Pengantar Kepada Membantu Guru Mengembangkan

Kompetensinya untuk Meningkatkan CBSA. Bandung:Tarsito.

Singgih.D.Gunarasa. 2004. Psikologi. Jogjakarta.

Slameto. 2003. Belajar dan Faktorfaktor yang Mempengaruhinya. Jakarta: Rineka Cipta.

Soewarso. 2000. Kreativitas Guru Dalam Mengajarkan Mata Pelajaran Ilmu Pengetahuan Sosial di Sekolah Dasar. Edukasi Th XI No. 2. Semarang: FIP Unnes.

Sugianto, Mayke. 2005. Bermain, Mainan dan Permainan. Jakarta: Departemen Pendidikan dan Kebudayaan.

Sugiyanto. 2001. Perkembangan dan Belajar Motorik. Jakarta:Depdiknas. 